\title{
Evaluating the Place of the Ekpe Traditional Institution as a Tool for Nation-Building in Pre-Colonial Cross River Region
}

\author{
Inyang Bassey ${ }^{1} \quad$ Charles E. Ekpo ${ }^{2 *}$ \\ 1.Department of History and International Studies, University of Calabar, Nigeria \\ 2.Post-Graduate Student, Peace and Conflict Studies Programme, Institute for Peace and Strategic Studies, \\ University of Ibadan, Nigeria
}

\begin{abstract}
The Cross River region is a vast socio-cultural mosaic which accommodates peoples of distinct ethnic, religious, social, economic and political inclinations. Its northern half is infact, the birth place of the Bantu group who are known to speak over 200 related languages. Amidst this plurality in culture, a traditional institution played a crucial role in the amalgamation of political structures which, if not for colonial intervention, could have engineered a nation out of these different socio-cultural groups; that traditional institution was the Ekpe institution. Literature on the proliferation and indeed imperium of Ekpe abounds. Yet, none explicitly explain the confederation which the Ekpe was at the process of engineering in the Cross River region before colonialism interrupted such progress. This work examines the unsung attempt by the Ekpe traditional institution to forge a confederation across the segmented peoples of the Cross River region. Utilizing primary and secondary evidences, it has been shown in the work that such efforts at nation-building were yielding results and would have maturated into a formidable central political unit but for colonial truncation.
\end{abstract}

Keywords: Ekpe, Old Calabar, Nation-building, Ekpe confederacy, Cross River Region

DOI: $10.7176 / \mathrm{HRL} / 49-02$

Publication date: August $31^{\text {st }} 2019$

\section{Introduction}

The upsurge of Afrocentric historiography in Africa in the second quarter of the 1950s and the decades that followed was a direct attempt by the earliest African scholars to make objective denotations from the subjective reports, documentaries, books and analysis bequeathed them by Eurocentric apologists. Incontrovertibly, an astronomical success has been made on greasing the rusted physiognomy of Africa's and Nigeria's past. Since man is a product of a society, such attempts at illuminating the interesting spheres of the peoples' history remains a perpetual process, hence, the justification of this work. An interesting aspect of the Southern Nigeria's history that this work seeks to bring to limelight is the remarkable attempts by the Ekpe traditional institution to melt the myriad of socio-cultural/political difference across the Cross River region in a single pot.

The Cross River region, also christened the Cross River basin, describes and encompasses the estuaries, territories or settlements along the river Cross. Succinctly, "the Cross River and its tributaries constitute the dominant geographical feature of the region" (Erim, 1990). The Cross River stretches from the present Benue State southwards and covers all the Cross River State and the eastern parts of Anambra, Imo and Akwa Ibom States and continues into the Mamfe Depression within which flows the upper courses of the Cross River in western Cameroon. In a quantitative representation, the river covers about 53,509 square kilometers of which 39,490 square kilometers fall within Nigeria while the remaining 14,100 square kilometers lie in the Cameroon Republic. About 49 percent (19,350 square kilometers) of the Cross River basin lies in the present Cross River State, 29 percent (11,452 square kilometers) fall within Anambra and Imo States and an area of 22 percent (8,688 square kilometers) situated in the Benue State (Petters, 1990).

It is a fact of history, ethnography, linguistics and archaeology that the Cross River region in the pre-colonial southern Nigeria housed a plethora of ethnically and socio-politically distinct groups who had evolved varying social norms and standards suited to the environment they found themselves. Subsequent migrations and splits had culminated in the emergence of a number of groups such as the Efik, Ibibio, Oron, Eket, Ibuno, splinter Ejagham groups and the Cross River Igbo. From the indices of language, customs and traditions, one could telescope or adduce an illusion of separateness, yet, the bond that glued the cultural tapestry of the Cross River region was quite sturdy and was in effect, amalgamating the socio-political opposites of the pre-colonial southern Nigeria.

Facilitating this socio-cultural amalgam was the river Cross which was a superhighway upon which extensive communication and intergroup relations manifested. As these various ethnic groups mingled, migrated, traded, intermarried and waged wars, a great cultural interchange occurred. As observed by Professor Okon Edet Uya,

the Cross River, with her major tributaries, has indeed been a highway for cultural interchange between the peoples of the region. Because it served as the major artery of communication for those who lived on its banks, the riverines peoples of the region - namely, the Oron, Uruan, Itu, Efik, Akunakuna, Umon, etc., through trade and fishing contacts gained intimate 
knowledge and experienced reciprocal influences on each other before the advent of the Europeans (Uya, 1987).

In what Alagoa (1980) nicknamed "the Benue-Cross Valley", the Cross River region had overtime become a linguistically compact region - hence, the categorization of the languages of the region under the Benue-Congo language group. Alagoa, identifying with Chief Okoi Arikpo, agrees that "most of the peoples of the Cross River valley relate how they migrated from somewhere north of the Cross River as a result of pressure from the Ankpa, and that the Efik-Ibibio, Aro's, Ejagham, Yakur, must come from an area somewhere in the valley of the Benue". The significance of seemingly different, but mutually intelligible languages and common traditions of migration cannot be overemphasized on the movement towards nationhood by the peoples of southern Nigeria during the pre-colonial days. Moreso, the fluidity of some social orientations, culture, traditional institutions and cult groups along the Cross River region leaves an empathetic mind curious on what would have happened in the Cross River region if colonialism did not obstruct that trajectory of indigenous political developments. The Cross River region, Alagoa (1980) has argued, was characterized by communities organized in segmented political systems deriving their stability social controls from various forms of societies or associations and age-grade organizations. One of such societies or traditional institutions which were pervasive in the Cross River region was the Ekpe traditional institution. This work discusses the place of the Ekpe institution in the pre-colonial Cross River region - pointing out the gains it had made towards nation-building.

\section{Conceptual Orientation and Framework}

In the first half of the nineteenth century, European powers and adventurists decelerated their efforts at exploring and cementing their influences across the 'virgin lands' discovered in Africa, Asia and Americas. This scenario was propelled by the emergence of frictions, schism and contradictions which of course, posed grave threats to the status quo. While primitive accumulation and exploitation had ensured a monumental rise in the standard of living of Europeans, mercantilism had placed existing polities on an orbit to wealth and technological innovations. The subsequent maturation of capitalism as a succeeding economic foundation warranted a befitting superstructure which of course meant the dismantling of the old order. The question on the delineation and composition of a nation capsized from being an exclusive prerogative of the monarchs to the citizens. Concerned citizens began to abhor with strong resentment, the idea of the monarchs carving a people of common language, culture, religion, belief system and political inclinations into different autonomous regions. Thus, the speakers of the German language agitated ostensibly for a nation of the German people. With ferocious actions climaxing in 1848 and 1870 , the Germans could boast of a nation-state. Same could be said of the Italians, Greeks, Belgians, and others. Through these nationalistic actions, groomed by the desire of a common people to share a common socio-political fate, the term "nation-building" invaded the lexicon of political discourses.

Nevertheless, it is doubtful if a process as described above can be adopted as a hallmark in proposing the process or concept of nation-building in Africa in general, and Nigeria in particular. Aside the experiment by the Amharic in Ethiopia, the process of a people evolving a nation out of a common historical and socio-political affinity was at its infant stage when the menace of colonialism plunged such development in Africa. Rather than the people or their monarchs defining the delineation of nations, the colonial overlords brazenly partitioned, based on their perceived gains, interests and administrative convenience, territories with antagonizing socio-cultural variables in Africa. In such a milieu, prospective nations were coerced into political union with others in an arbitrary manner and on volatile/fragile foundations. In the words of Ekpo \& Chime (2016), "colonialism led to the creation of artificial and arbitrary [nation] state across ethnic, cultural and political boundaries". This has not just complicated the challenge of nation-building but also the definition of such concept in an African perspective.

In regard to the above, Ekpo \& Chime (2016) have reckoned nation-building in the African case to be "efforts by African states to form a formidable, stable and united state out of a conglomeration of different nations lumped together by the colonialists".

More so, nation-building in our own case is in retrospect of what would have become of southern Nigeria, based on the Ekpe factor, if the Europeans had not derailed its progress at gradually transforming the region into a single political orbit. Hence, nation-building in this work is defined as a direct or indirect, conscious or unconscious efforts, steps or gestures by a socio-culturally heterogeneous peoples to, based on those things that unite them or have the potency of unifying them, evolve a firm and central political unit for the betterment of all its components and units. On this idea, the philosophical basis of this work is anchored.

\section{The Origins and Evolution of Ekpe Traditional Institution}

Precision on dates patterning to the origins and evolution of the Ekpe traditional institution in the Cross River region has remained elusive to interested scholars due to limited evidences. Focusing on the Efik of Old Calabar, Latham (1973) has suggested that the Ekpe society "must have been founded at the earliest about 1720. But a more reasonable estimate would place the date of foundation of Ekpe closer to the middle of the [eighteenth] century". It is however certain that the Ekpe which originated from the Cross River interior had "existed for a long time, 
since well before the first documented records of this region" and seems to have "pervaded the interior as far inland as several hundred kilometers by the seventeenth century" (Lovejoy, 2012).

The Ekpe society unarguably originated from the Cross River region. The controvertible clause however, is which part of the Cross River region specifically the society originated from. According to Aye (1967), Ekpe, often known to the early Europeans as Egbo, was and is a secret society, a sort of freemasonry, originally said to have been introduced in Calabar from Usak Edet, a segment of the Ekoi people. Hence, the birth place of Ekpe, Noah (1980) contends, is the Ekoi country. In a more detailed analysis, Jones \& Salmons (2011), have explained that the Qua of Calabar had originally come from the Usak Edet region to the south east of modern boundary of Cameroon with the Ekpe cult. That it was through the Qua [an Ejagham or Ekoi stock], that the secret of Ekpe cult diffused to Calabar.

In his well researched thesis titled "Ekpe Imperium in South Eastern Nigeria...", Anwana (2002) identified a plenitude of evidences to validate the Ejagham/Ekoi origins of the Ekpe society. According to him, Ekpe originated among the Ejagham as an integrating force in about the sixteenth century. More so, the symbolic words or language used in greeting or addressing Ekpe assembly is of Ejagham origin - the words in all Ekpe incantation and salutation starts with Oje! Oje! Mgbe or Ekpe, or Oje Bari Ekpe! is said to be an expression of Ejagham. While section of Ejagham chieftain admits the phrase Oje! Oje! Bari to mean "Order! Order! come and 'eat', Mgbe", others construe it to be "Order! Order! come there is a way perhaps out of any situation with Mgbe". More so, an Ekpe title of Eyamba or Iyamba is said to be an Ejagham terminology from the two words Eya and Aya meaning "open" and Mba meaning "way" or "road". Eyamba is therefore "an Ejagham word for leader that must show others the way in life or a pathfinder" (Anwana, 2002). Also, there is a labyrinth of evidence which testify that Nsibidi language, utilized by the Ekpe is a heritage of the Ejagham. Succinctly, the songs rendered by Ekpe initiates lay credence to the Ejagham origin of Ekpe. Anwana (2002) has reproduced one, thus:

\section{Ekpe Song}

Iyamkpe eyen okopedi Iyamkpe okoto okopedi Iyamkpe eyen okopedi

Iyamkpe okoto mmong edi okopedi? Iyamkpe okoto Efik Odo eke atam-a? Osuk edi kpakiet oro? Efik ekom Ekoi Iyamkpe oto akai Ekoi eye!

eye!

eye!

eye!

eye!

eye!

eye!

eye!

eye!

\section{Translation in English}

Iyamkpe the child of okopedi

Iyamkpe came from okopedi

Iyamkpe the child of okopedi

eye!

eye!

eye!

From where did Iyamkpe come to okopedi eye! Iyamkpe came from the Efik What about that of Atam? Is it still the same?

eye!

eye!

eye!

The Efik be thankful to Ekoi

eye!

Iyamkpe came from Ekoi forest

Of course, as an ethnographic data which "testify to their earlier usage in the past", the lyrics of such song is invaluable in this regard.

Disputing the Ejagham/Ekoi origins of the Ekpe society is Akak (1995). In his rebuttals, he posits that the Ekpe cult neither originated in Ekoi nor Qua because "nearly all the existing Ekpe lodges are those of Ekpe Efik Iboku, Ekpe Efut, Ekpe Itako, Ekpe Usak Edet, etc; with nothing whatsoever anywhere as Ekpe Ekoi nor of the Bantus, nor Abakpa nor Qua". In another publication, Akak (1982) traces the historical antecedents of the Ekpe society to the secret Ekpe institution known as Nyana-Yaku. According to the author, when the Efik left Uruan to their present settlements, they came in contact with the Efuts, from whom they acquired something very similar to their own Nyana-Yaku. One Efut man Archibong Ekondo from Usak Edet, Akak (1982) insists, bought and sold the secrets of five small Ekpe grades to the Efik at Creek Town during the reign of Eyo Ema Atai and his wife Mutaka. These five small grades were Mkpe, Ebonko, Bakara, Mboko and Mboko-Mboko. Ekpe, Akak (1982) contends, was already an equivalent of Efik Nyana-Yaku which finally evolved into Mkpe society. Thus, Ekpe secret society or fraternity:

is of Efik origin, starting first in the form of Nyana-Nyaku or Mkpe before being evolved into its present form through Efik's early contact with the Efut couple. The fact that present Ekpe cult was originally known by the Efik as Nyana-Yaku and not as Ekpe, cannot in anywhere rule out the people's claim to its originality. The change in name merely follows new developments in the process of evolution (Akak, 1982).

In a seeming solidarity with Akak, Offiong (1989) avers that "those places within the Cross River State that posses the society either bought it directly from the Efik, or from those who themselves bought from the Efik".

At loggerheads with the proponents of Efik origins of the Ekpe society is Essien (1993), who maintains that "the need to maintain laws and orders in Uruan village and in Essien Uruan prompted Uruan people in south western Cameroon to evolve a belief in Ekpe. Arbitrating for the Efik and Uruan adherents, Bassey (2011) conjectured that:

Efik have not denied that the Uruan people had Ekpe when they were with them. What some are claiming is that they, Efik had an Ekpe equivalent by the 
name Nyama-Nyaku. If this claim were true, why did they abandon it for Ekpe? Proud people of Efik would not have abandoned their own thing for an equivalent unless they did not have what they are claiming or what they had was inferior, therefore, not Ekpe. If they had their own thing, they would at least have given it their own name. The words Nyama-Nyaku are certainly not Efik. If Nyama-Nyaku had any relevance of note in Ekpe, it would have found acknowledgement in Efemba, a secret display of Ekpe artifacts in cultural and historical setting. It is likely that the Efik acquired some lower grades of Ekpe either before or while in Uruan.

In light of the quote above, if the Efik had acquired the Ekpe secrets before their migration to Uruan, they probably did that through the Ekoi who according to Abalogu (1978) were the suppliers of such secrets to Ibom, a previous Efik settlement before their migration to Uruan.

There is also an Ibibio origin of the Ekpe cult. Proponents of this debate argue that the Ekpe originated in Ibibio and that the Efik acquired it from Uruan and continued with the system when they migrated to their present abode. The group claims their position is 'evidenced' by the fact that when Ekpe Efik masquerade wants to move out of the lodge, the head of that grade of Ekpe had to use Ibibio language to command it out after which the language will be reverted to Efik. The position of this school is however, a factoid and has thus been debunked by Anwana (2002) for the disciples of this school have failed to state which Ibibio language is usually used in such in such occasions. Anwana has also observed that the word "Ekpe" itself is not of Ibibio origin and wonders why Uruan, Itu and Ikpe would have purchased the secrets of Ekpe from Efik when by proximity, Ibibio offered a comparative advantage.

Based on available evidences as recounted above, the Ekpe traditional institution has evolved and spread across the Cross River area as early as the sixteenth century. Its epicenter is most likely the Ekoi country from where it disseminated to other areas of the Cross River region.

\section{The Nature and Structure of the Ekpe Traditional Society}

The Ekpe society was an association in the form of organized corporate groups (Nair, 1972). Ekpe (leopard) was said to be a mysterious and invisible being inhabiting the forest which cannot be seen by the uninitiated. It had certain secret rituals whose performance can only be conducted by members of the fraternity (Aye, 1967). The society possessed a plot land known as Ikot Ekpe (in Efik) where members don costumes and observe ceremonies safe from the intrusion of the uninitiated who never dare enter the precincts (Simmons, 1968). The Ekpe was indeed propitiated for the good of the entire community. As a mysterious being, only its roaring could be heard by everyone in the community. Since it could not be seen, it had a physical representative, a masquerade called Okum Mgbe (Ejagham), Idem Ikwo (Efik), or Idim Ekpe (Oron) (Anwana, 2002). The masquerade in the words of Simmons (1968) reflected: "the society's costumed figure Idem Ikwo, wears a belt tied on his hip and carries a whip; the tinkling of the bell announces his approach to all the uninitiated, who flee from him if they desire to escape being whipped. He is always accompanied by members of the society to the society's bush, where he takes off his costume" (See Appendixes 1, 3, 4 \& 5). In the right hand of the Ekpe masquerade, carried a staff, while in his left a bunch of leaves and across his forehead a feather is stuck. This, Aye (1967) contends, was the physical or visible representation of the society. The philosophical basis of the Ekpe traditional institution is expressed by Anwana (2002) when he averred that:

Ekpe institution found expression with those ritual acts which enabled man to empathize physically and come to terms with those forces which posed fears and threatened his very existence. In a bid to empathize, however, man evolved drama since he wanted to introduce some elements of impersonation (sole play) into life as a means of propitiating the gods and therefore perpetuate his compulsive needs, in sanctity and security in world which threatened annihilation from all directions.

Ekpe cult was reserved for males, mostly of freeborn. Membership to the Ekpe society especially in lower Cross River region - particularly among the Efik, Efut, Eket, Ibibio, Qua-Ejagham and Uruan - was exclusive of women's participation. An Ekpe chieftain however, could be allowed to initiate any of his daughters into Ekpe society but such initiation was usually "honorary and cosmetic" (Miller \& Ojong, 2012). Situations, perhaps, must have been a bit more conducive for women's participation in the Ohafia area of the Cross River region. Here, one Nne Uko, a woman of the village of Akanu, is known to have married two wives, joined various men's cults including the Ekpe society and even gained the right to dance with men when they performed the Ohafia warrior's dance. Another of such women who was an Ekpe initiate was named Dike Nwami (McCall, 1996). 
Huge sums of money were paid by would be members upon their initiation to it and still much more by those who aspired to acquire its titles (Akak, 1982). Ekpe, just like other societies was graded.

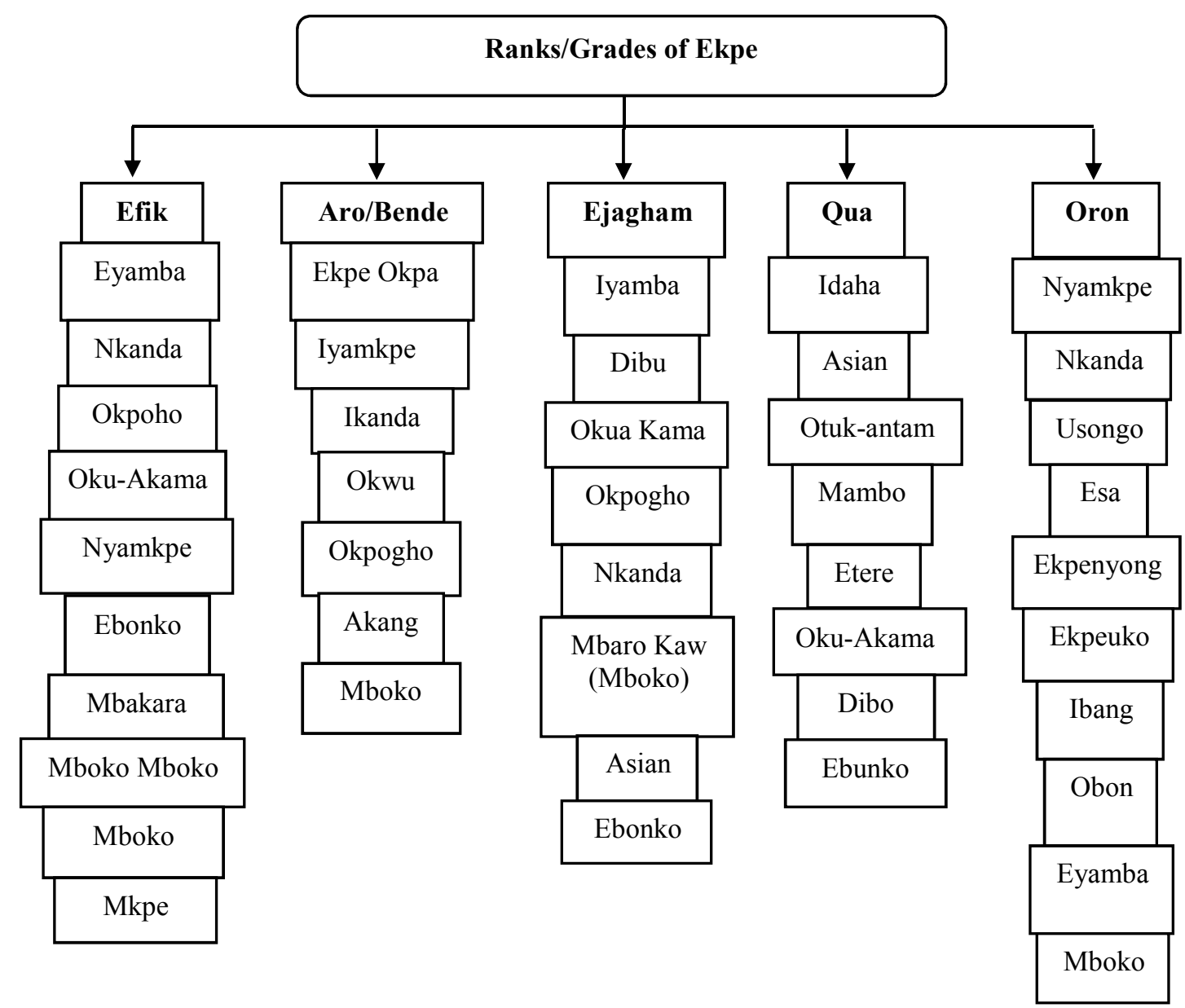

Sources: organized by the authors with data from: Anwana (2002); Aye (1967), Nair (1972) \& Abalogu (1978).

A new entrant paid fees appropriate to each grade between at least twelve months intervals. Each grade had its peculiar rituals, its dances and dress and to the novice are shown, proper to the grade he is about to enter and peculiar to it. Members of the grades were also distinguished by items of dress: cock's and peacock's feathers were worn by the first, second, third and fourth grades. The ostrich feather was conferred on entrance into the fifth grade and worn by the sixth, seventh and eighth - "the society naturally underwent changes as it entered each new community, and also through time in each community" (Alagoa, 1980).

Initiation into the Ekpe was elaborate. To reach the top grade, one must go through three main stages: Ekpe ufok (extended family Ekpe), Ekpe essien (lineage Ekpe) and Ekpe obio (town Ekpe). The grades are divided into three stages, which are based on the structure of the social organization. At each stage, initiation dues are paid in the forms of money, food, drinks and goats. At the ceremony, performed as the compound of the head of each initiatory stage, camwood dust is sprinkled on the hair of the initiate (Ekpo, 1978). 


\section{Stages in Ekpe Initiation Rituals}

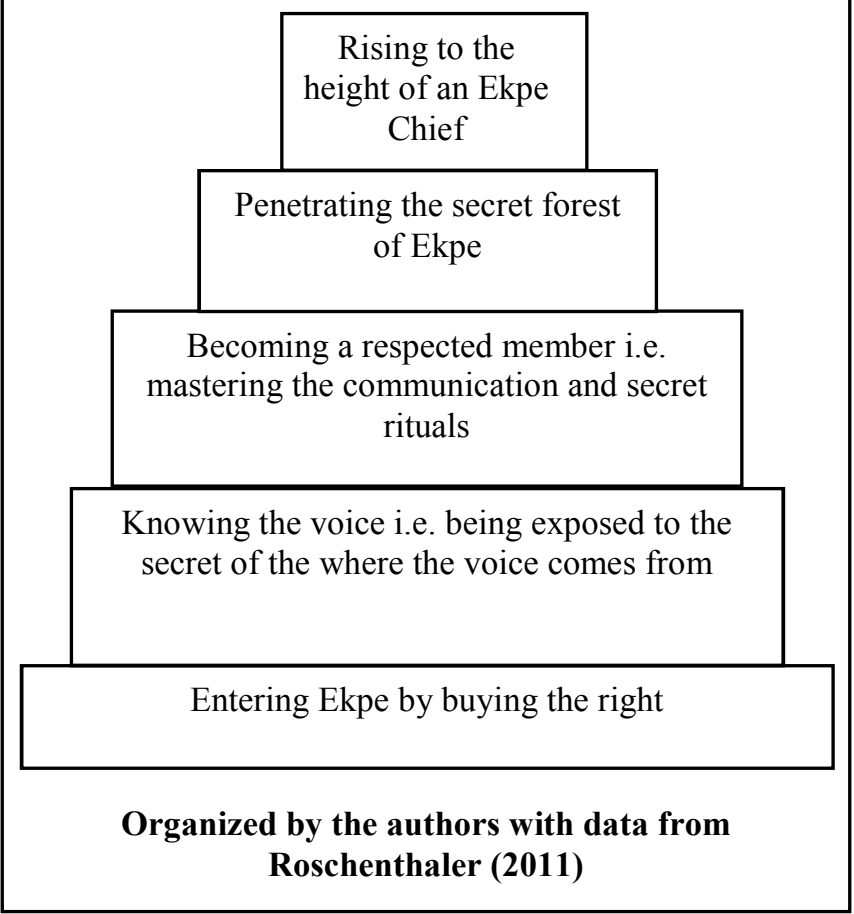

The Nsibidi which Alagoa (1980) has defined as the "reduction into writing of sign language used in the Ekpe, Ukpotio, and IsongEsil societies" revealed to Ekpe members who are fully initiated into the institution. Nsibidi manifested in the form of gesture with hand, walking stick, body movement and even facial expression (Anwana, 2002).

The Ekpe cult according to Akak (1982) served political, economic and social functions. Politically, it represented the highest institution of government, having supreme power of life and death. No one or group of persons could challenge any decision of the society which often settled various major disputes and cases between individuals or groups of individuals. Its judgment was final and could not be appealed. The Ekpe institution thus wielded both judicial and legislative powers across most settlements of the Cross River region. Economically, it formed resourceful potentialities for its members who normally shared the initiation fees and fines paid by both members and non-members. Members' regional interest was also enhanced. Socially, the Ekpe as the supreme authority helped the weak and the poor from operation and injustice from the rich and powerful nobles, since the former also had equal rights to present their case to the society. This made it members to endeavour to keep clean records which had to be considered in the process of promotion to higher grades.

\section{Proliferation of the Ekpe Traditional Society across the Cross River Region: Movement to Nationhood?} Ottenberg \& Knudsen (1985) have explicitly demonstrated how the Ekpe traditional institution proliferated across the Cross River regional settlements of Cameroon (Grass fields Groups), Banyan, Bangwa, Ekuri, Akunakuna, Yako, Mbembe, Igbo, Ibibio, Anang, Ejagham country, Efik, Mbo and Balundu of south west Cameroon (See Appendix 2). Jones (1973) has also revealed how the Anang and Ibibio, upon acquiring the beautiful female Ekpe heads, sold some of their copies to the southern Ikwerri Ibo of the Ahoada division where they appear in the Okorosie water spirit masquerades. In the Umuahia area of the Cross River region, Ekpe secret society had spread to many villages under various names such as Ekpe, Akang, Okonko, Mbom, etc (Jones, 1973).

Wherever Ekpe pervaded, it replaced the conventional governance structures, of such place. In Ugep, the Ekpe was the supreme authority of which "no one dares to abuse its decision" (Ikpi, 2007). In Arochukwu and Bende, it was the most influential organization which overshadowed all others. Infact, "having assumed the political leadership in the community [Ekpe] became the government of the day... made laws and enforced them and its judicial powers were far-reaching in effect" (Abalogu, 1978). In the words of Roschenthaler (2011),

Ekpe was also governing among the Efik, and the Efut in Calabar, in Itu,

Uruan and Oron, which it had reached early. In Oron, it replaced the governing association Isong, and among the Efik, the Ekpu or Ekpo society. It also had this function in the Igbo villages of Arochukwu where it was called Okonggo, and among the small village groups in the forest west of the Ejagham.

Since political organization in the Cross River region was in segment, "a shared institution like Ekpe functioned to integrate communities (Miller \& Ojong, 2012) and condemned the whole region into one political orbit. Ekpe, by modulating the power levers of the pre-colonial Cross River region "united the local community and fostered integration among the peoples of Ejagham, Efik, Ibibio, Oron [etc.] as well as Cross River Igbo. It was an instrument that rendered individuals and groups "absolutely sovereign" in their own houses and united the forces of all against any enemy whether external aggression or civil disorder" (Anwana, 2002).

It was conventional and infact necessary that the highest ranked in Ekpe society in a particular area, assume leadership of such geographical entity. Thus, the leaders of Ekpe across the Cross River region became the centre upon which political power revolved. Since it was an "aberration for a family, lineage, village, or clan head not to become an initiate and a high ranking official of Ekpe" (Anwana, 2002), rulers of states in the Cross River region became co-equals bounded by ranks and a common form of government and political philosophy. To aptly put it, 
the region was in the process of evolving what would have looked like a confederation where separate developments would have been encouraged but under a common political or governance structure. The variables of confederation become more conspicuous in the nineteenth century when refurbished grades of the Ekpe society began to recycle into the central and northern fringes of the Cross River region. By this period, purchasing Ekpe from a particular group guaranteed drastic revolution in economic, social and political structures (Anwana, 2002) and the 'purchasees' "expected the new owners to cooperate in diplomatic matters and to invite each other to important festivities concerning the acquired institution" (Roschenthaler, 2004). Since by the nineteenth century, the recycling of Ekpe northwards "over the trade routes from the Efik area into the Ibibio, Anang, and Igbo regions and to the other groups in the Cross River, returning to Ejagham and other nearby peoples in more extensive form" (Ottenberg \& Knudsen, 1985), Calabar fortuitously braced up for an encroaching role as a potential capital of the Cross River confederation. Akak (1982) acknowledge this presupposition when he posited that the Ekpe titles bought from Calabar by non-Efik with a view to introducing them to their own people established an umbilical cord which connected the 'purchaser' with the 'purchasee'. According to him, when such purchase was made, "their Ekpe lodge becomes a branch of the Ekpe Efik Iboku confederation with the headquarters at Duke Town".

The idea of an Ekpe confederation in the Cross River region is further echoed by Reverend Hope Waddell who on his visit to King Eyo Honesty at Creek Town in the 1840s was "privileged to witness a grand and rare Egbo [Ekpe] ceremonial". According to hm,

Some persons of consequence had come from a far country to purchase the honours and authority of that institution, that they might introduce it among their own peoples, and become the founders of a new branch. This was equivalent to entering a confederation of which Calabar was the head, and they were consequently treated with distinguished respect. It was a public display of Egbo grandeur, and all the towns people were allowed to come forth and witness it (Waddell, 1863).

Since a "village that did not purchase Ekpesoon became completely isolated" (Roschenthaler, 2011), the rush for the purchase of Ekpe grades skyrocketed. The result was not just a gradual political amalgamation from the top but also a seeming porosity of hitherto jealously guarded borders and trading posts. One Ita Agua of Akim Qua Town in Calabar had unlimited access to the trade in Oban area because of his exalted position in Mgbe [Ekpe] society back home (Tangban, 2003). Thus, Ekpe initiates in the Cross River area became regional citizens whose interest, security and rights defied bounds. For instance, Tangban (2003) has documented a case where dispute between one Ebuta Ekure of Abia village and Bichene Oru of Bendeghe Ekiem village over a woman named Awu was arbitrated and solved by Ekpe society in Ikom. Hence, "the wide diffusion of Ekpe over the Cross River region gave members of Ekpe immunity and privileges wherever they went among other members of Ekpe. Ekpe became an instrument of inter-group authority able to assure its members redress of grievances over the entire [Cross River] area" (Alagoa, 1980). Such immunity and privileges granted these 'regional citizens' did not only facilitate trade but enabled initiates to "travel from one part of the river basin to another without molestation" (Ifemesia, 1978).

Importantly, the Cross River region had collapsed into a single language and scripting zone where despite linguistics differences, blossomed a regional script christened Nsibidi. As observed by Abalogu (1978), the Nsibidi was a sign language of the Ekpe cult which in pragmatic sense, was not meant for everybody. It was the language of the adepts of the Ekpe society. It was indispensable that a member of Ekpe cult know the code sign or password which served as its identity for the attainment of any particular grade in Ekpe circle. As the Ekpe institution went viral, the language suffused the entire Cross River area. In areas where the Ekpe cult was yet to convincingly permeate and successfully wrestle traditional powers from antagonizing and schismatic cult elements, the Nsibidi acted as the 'interpreter' and facilitator of Ekpe ascendency in such regions. The Nsibidi language was of course, not a peculiarity of the Ekpe institution. Carlson (2007) admits that Nsibidi script was not limited to the Ekpe organization alone; "it use by multiple ethnic groups and numerous ritual associations produced a wide range of practices that often makes [the Nsibidi] interesting and hard to define". Aside political implications, the Nsibidi had dramatic influence over the arts of the Cross River region where writing, art and ritual were extricably linked (Carlson, 2007).

Thus, by the second decade of the nineteenth century, the forces (of which the Ekpe championed) unifying the socio-political tentacles of the Cross River region had almost succeeded in building a nation out of the diverse people of the Cross River region. Since the process of nation-building in the Cross River region was still at its neophytic stage by the $1880 \mathrm{~s}$, it was natural that the colonial masters truncate such process to better their 'prestigious' divide and rule policy.

\section{Conclusion}

Previous authors researching on the Cross River region such as Akak (1982), Anwana (2002), Ottenberg \& Knudsen (1985), Abalogu (1978), Roschenthaler (2004; 2011) and others cited in this paper have convincingly discussed the proliferation and indeed the strength of the Ekpe cult among the ruling class of the pre-colonial Cross 
River region. Anwana (2002) specifically has done an extensive work defining how the Ekpe cult became a one party structure upon which every ruler in the Cross River basin 'must' belong.

Certainly, the fact that Ekpe imperium had sprouted its tentacles across the Cross River basin remains incontrovertible and has been duly justified by myriad of researches. However, very few authors have deemed it pertinent to consider the gradual concentration and consolidation of power in the Cross River region under a confederation of Ekpe ruled states with a possible headquarters at Calabar. Although Akak (1982), Aye (1967), and Waddell (1863) dedicated one or few lines to this respect, the gradual movement or transformation of the Cross River region into a nation-state by the Ekpe and its 'peripherals' has been the gap this work has filled. The work has done justice in this regard by recounting the strides made by the Ekpe at unifying the Cross River region into a single political orbit or confederation. As indicated in this work, the second phase of Ekpe proliferation which epicenter switched to the southern Cross River area of Calabar designed a form of a strong bond between the purchaser and the 'purchasee'. This trend, it is premised, would have made the difference but for obstruction by colonial forces.

\section{References}

Abalogu, U. N. (1978). "Ekpe Society in Arochukwu and Bende". Nigeria Magazine, (126/127): pp.78-97.

Adediran, N. M (1996). An Exhibition on Old Calabar in Retrospect. Nigeria: National Commission for Museum \& Monuments.

Akak, E. O. (1982). Efik of Old Calabar, Vol. III: Culture and Superstition. Calabar: Akak and Sons.

Akak, E. O. (1995). The Quas: Origin and History - A Handbook for Research Students, Scholars and the Public. Calabar: Akak \& Sons.

Alagoa, E. J. (1980). "The Peoples of the Cross River Valley and the Eastern Niger Delta" In Ikime, O. (ed) Groundwork of Nigerian History. Ibadan: Heinemann Educational Books (Nigeria) Plc.

Anwana, A. O. (2002). Ekpe Imperium in South Eastern Nigeria, 1600-1900. PhD Thesis Submitted to the Department of History and International Studies, University of Calabar, Nigeria.

Aye, E. U. (1967). Old Calabar through the Centuries. Calabar: Hope Waddell Press.

Bassey, B. E. (2001). Ekpe Efik: A Theosophical Perspective. Canada: Trafford Publishing.

Battestini, S. P. (2002). "Nsibidi". In Ottenberg, S. (ed) The Nsuka Artists and Nigerian Contemporary Art. Washington: University of Washington Press.

Brown, C. A. \& Lovejoy, P. E. (eds) (2011). Bight of Biafra and the African Diaspora. Trenton, NJ: Africa World Press, Inc.

Carlson, A. (2007). "Nsibidi: Old and New Scripts”. In Kreamer, C. M. et al (eds.) Inscribing Meaning: Writing and Graphic Systems in African Art. Smithsonian: National Museum of Art.

Ekpo, C. E. \& Chime, J. (2016). "Democracy and Revolution as Tools for Nation-Building in Africa". The Journal of Social Sciences Research, 2(8): pp.152-158.

Ekpo, I. A. (1978). "Ekpe Costume of the Cross River". African Arts, 12(1), November: pp.73-108.

Erim, E. O. (1990). "The Early History of the Peoples of the Upper Cross River Region". In Jaja, S. O et al (eds) History and Culture of the Upper Cross River. Enugu: Harris Publishers Ltd.

Essien, D. (1993). Uruan People in Nigerian History. Uyo: Modern Business Press Ltd.

Ifemesia, C. C. (1978). Southern Nigerian in the Nineteenth Century: An Introductory Analysis. New York: NOK Publishers (Nigeria) Ltd.

Ikpi, O. O. (2007). Ugep and her New Yam Festival: Leboku a Rich Inheritance. Calabar: Gladen Digital Company.

Jones, D. \& Salmons, J. (2011). "Changing Styles: An Introduction to the History of the Art in Cross River". In Jones, D. (ed) Masquerades Mosaic: Charles Patridge's Collection from Eastern Nigeria, 1903-1913. Ipswich: Colchester and Ipswich Museum Service.

Jones, G. I. (1973). "Sculpture of Umuahia Area of Nigeria”. African Arts, 6(4) Summer: pp.58-63+96.

Kalu, O. U. (1980). "Writing in Pre-Colonial Africa: A Case Study of Nsibidi”. In Kalu, O. U. (ed). Readings in African Humanities: African Cultural Development. Enugu: Fourth Dimension Publishing Co. Ltd.

Latham, A. J. H. (1973). Old Calabar, 1600-1891: the Impact of the International Economy Upon a Traditional Society. Oxford: Clarendon Press.

Lovejoy, P. E. (2012). "Transformation of Ekpe Masquerade in African Diaspora". Carnival, Theory and Practice: pp.127-152.

McCall, J. C. (1996). "Portrait of a Brave Woman”. American Anthropologist, 98(1), March: pp.127-136.

Miller, I. \& Ojong, M. (2012). "Ekpe 'Leopard' Society in Africa and the Americas: Influence and Values of an Ancient Tradition". Ethnic and Racial Studies, iFirst Articles, pp.1-16.

Nair, K. K. (1972). Politics and Society in South Eastern Nigeria, 1841-1906. London: Frank Cass and Company Limited.

Noah, M. E. (1980). Old Calabar: The City States and the Europeans, 1800-1885. Uyo: Scholars Press (Nig) Ltd. Offiong, D. A. (1989). Continuity and Change in Some Traditional Societies of Nigeria. Zaria: Ahmadu Bello 
University Press Ltd.

Ottenberg \& Knudsen, L. (1985). “Leopard Society Masquerades: Symbolism and Diffusion”. African Arts, 18(2) February: pp.37-44+93+103-104.

Petters, S. W. (1990). "The Physical Environment of the Upper Cross River Area” In Jaja, S. O et al (eds) History and Culture of the Upper Cross River. Enugu: Harris Publishers Ltd.

Roschenthaler, U. (2004). "Transacting Obasinjom: The Dimension of a Cult Agency in the Cross River Area". Africa: Journal of International African Institute, 74(2): pp.241-276.

Roschenthaler, U. (2011). Purchasing Culture: the Dissemination of Associations in Cross River Region of Cameroon and Nigeria. New Jersey: Africa World Press.

Simmons, D. C. (1968). "An Ethnographic Sketch of the Efik People”. In Forde, D. (ed) Efik Traders of Old Calabar. London: Dawsons of Pall Mall.

Tangban, O. E. (2003). "The Mgbe Society and Inter-group Relations in the Cross River Area of Nigeria, 18001988”. In Akinyele, R. T. (ed) Race Ethnicity and Nation-Building in Africa: Studies in Inter-group Relations. Rex Charles Publication.

Uya, O. E. (1987). "History, Culture and Unity in the Cross River Region” In Abasiattai, M. B. (ed) The Role of the Arts in Nation-Building. Calabar: MAP Publishers Ltd.

Uya, O. E. (2002). African History: Some Problems in Methodology and Perspectives. Calabar: CATS Publishers.

Waddell, H. M. (1863). Twenty-Nine Years in the West Indies and Central Africa: A Review of Missionary Work and Adventure, 1829-1858. London: T. Nelson and Sons, Paternoster Row.

\section{Appendix 1:}

\section{Appendixes}

A Pictorial Representation of the Ekpe Masquerade

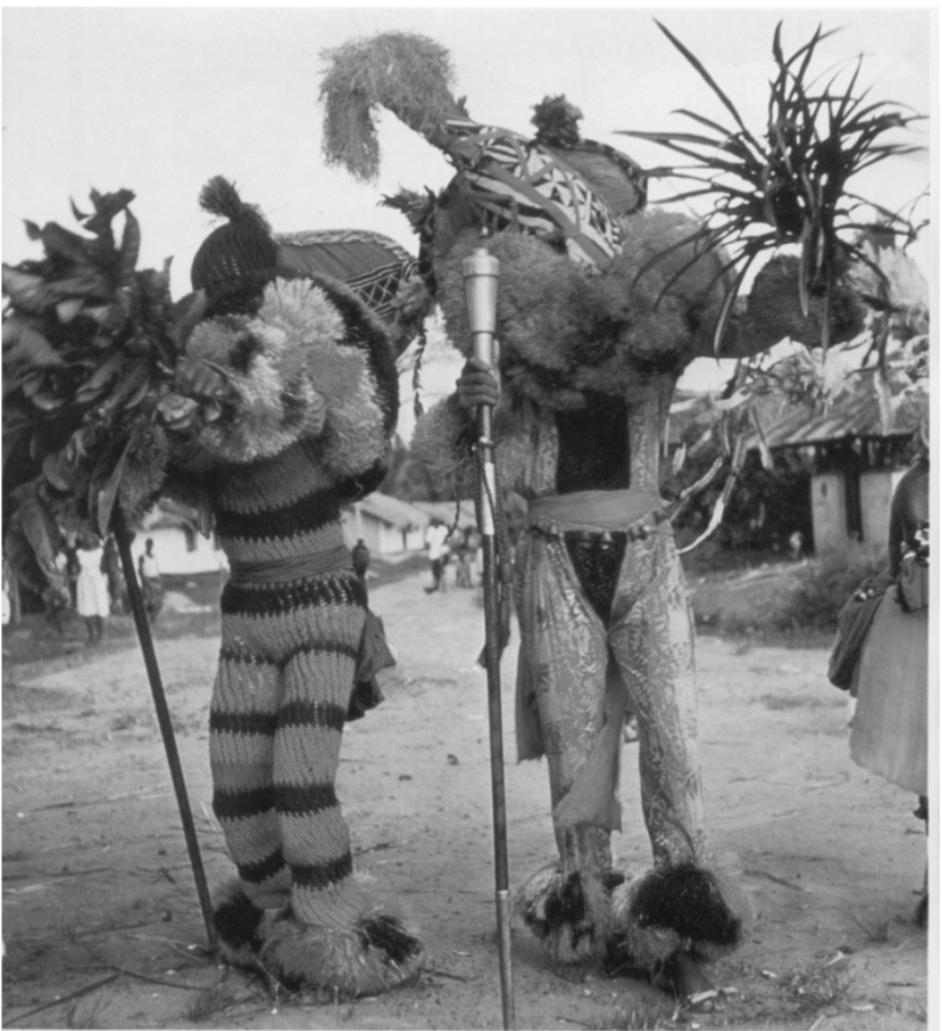

Source: Ekpo (1978). 


\section{Appendix 2:}

Map Showing the Directions of the Proliferation of Ekpe Traditional Institution in the Cross River Region

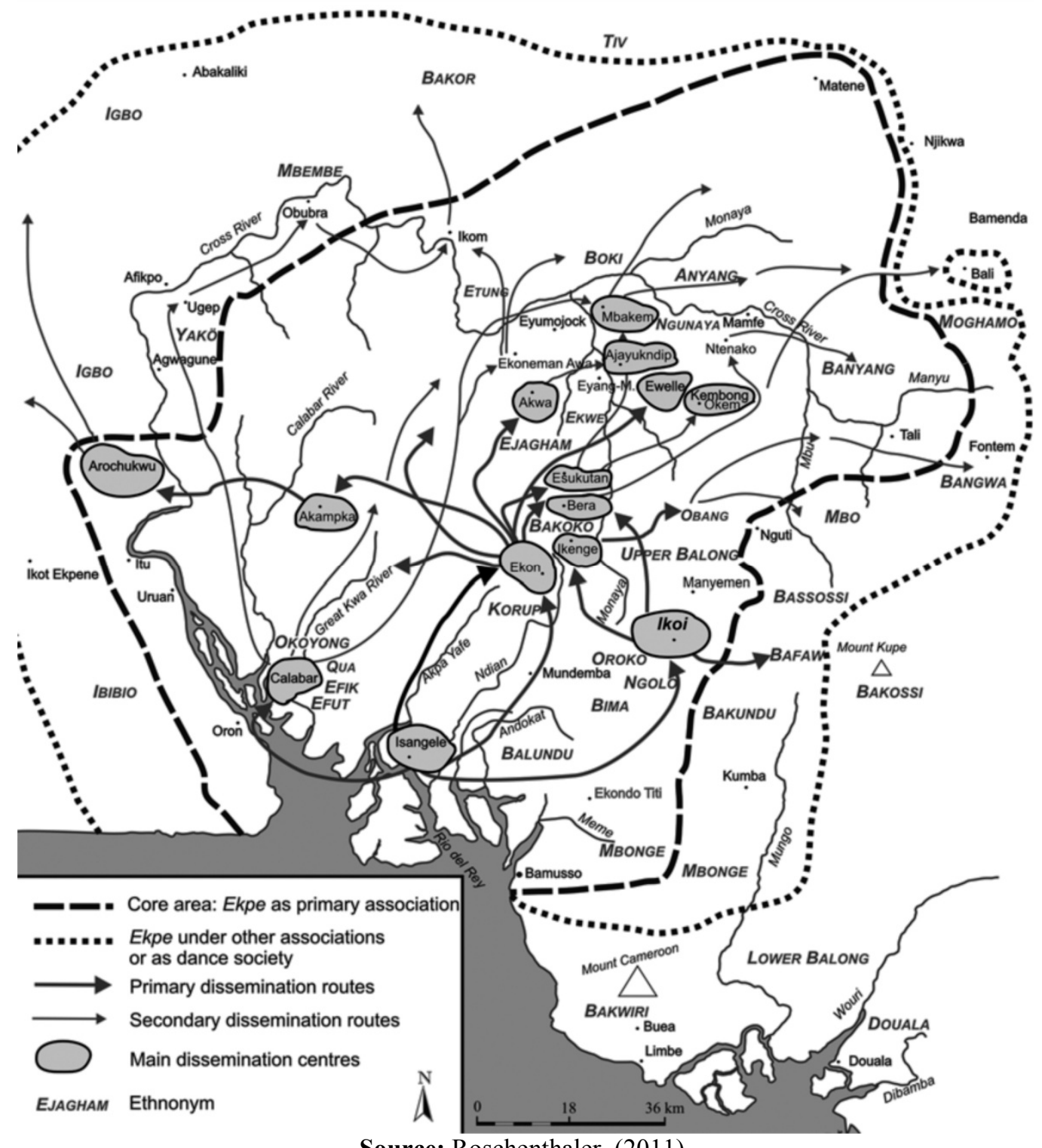

Source: Roschenthaler, (2011). 


\section{Appendix 3:}

Ekpe Dancer bows in front of Ekpe Chiefs

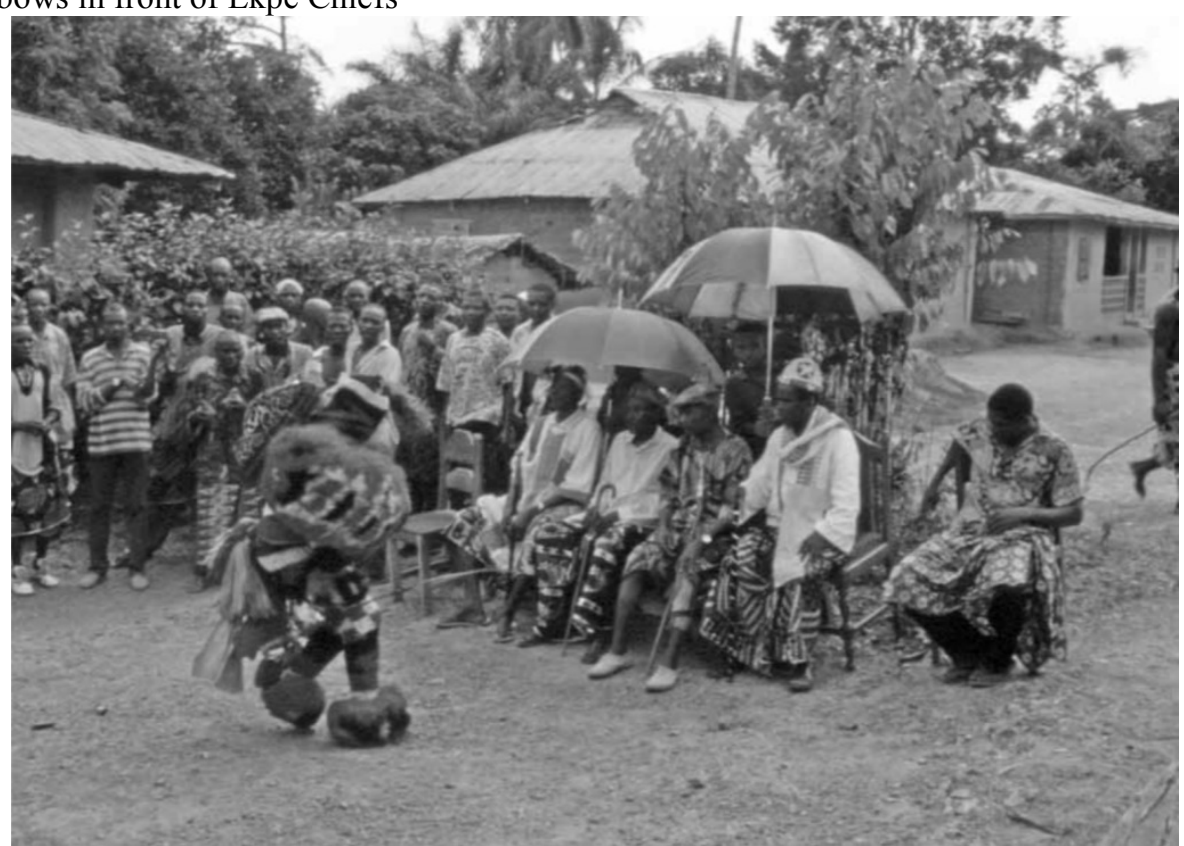

Source: Roschenthaler, (2011).

Appendix 4:

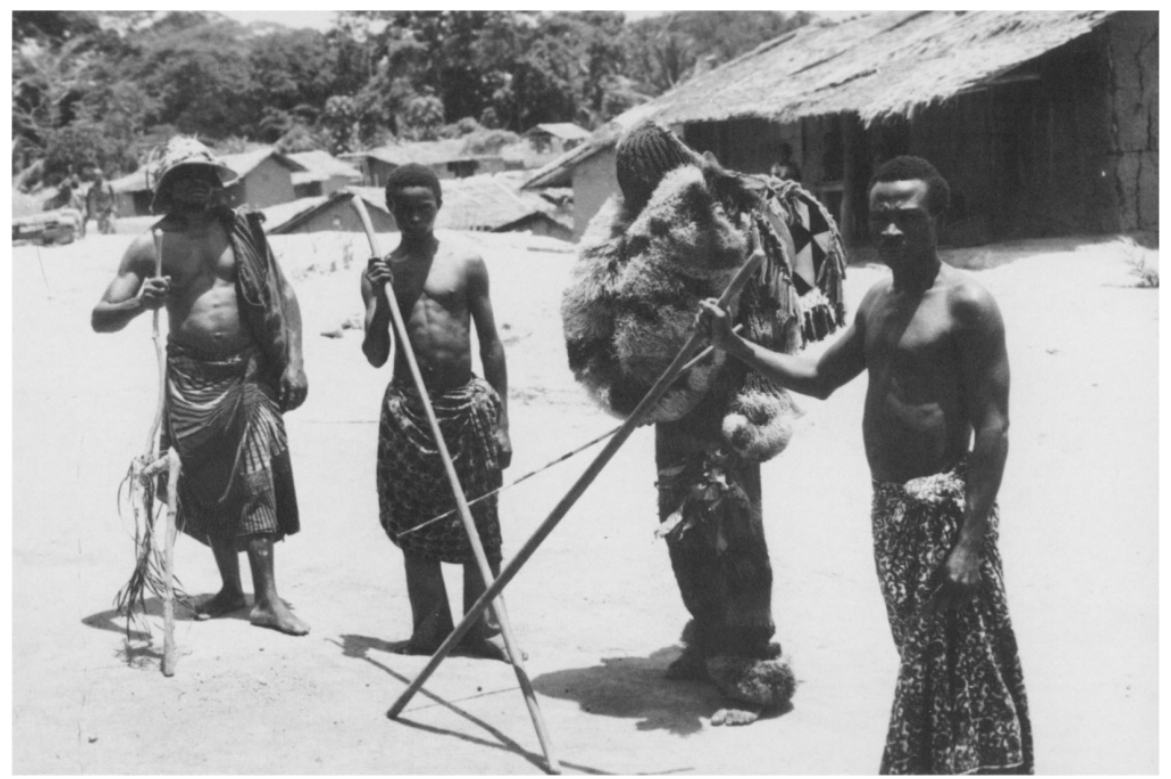

Nkanda Ekpe Grade performance in Central Cross River Source: Ottenberg \& Knudsen (1985). 


\section{Appendix 5:}

Ekpe Masquerade Performing Nsibidi

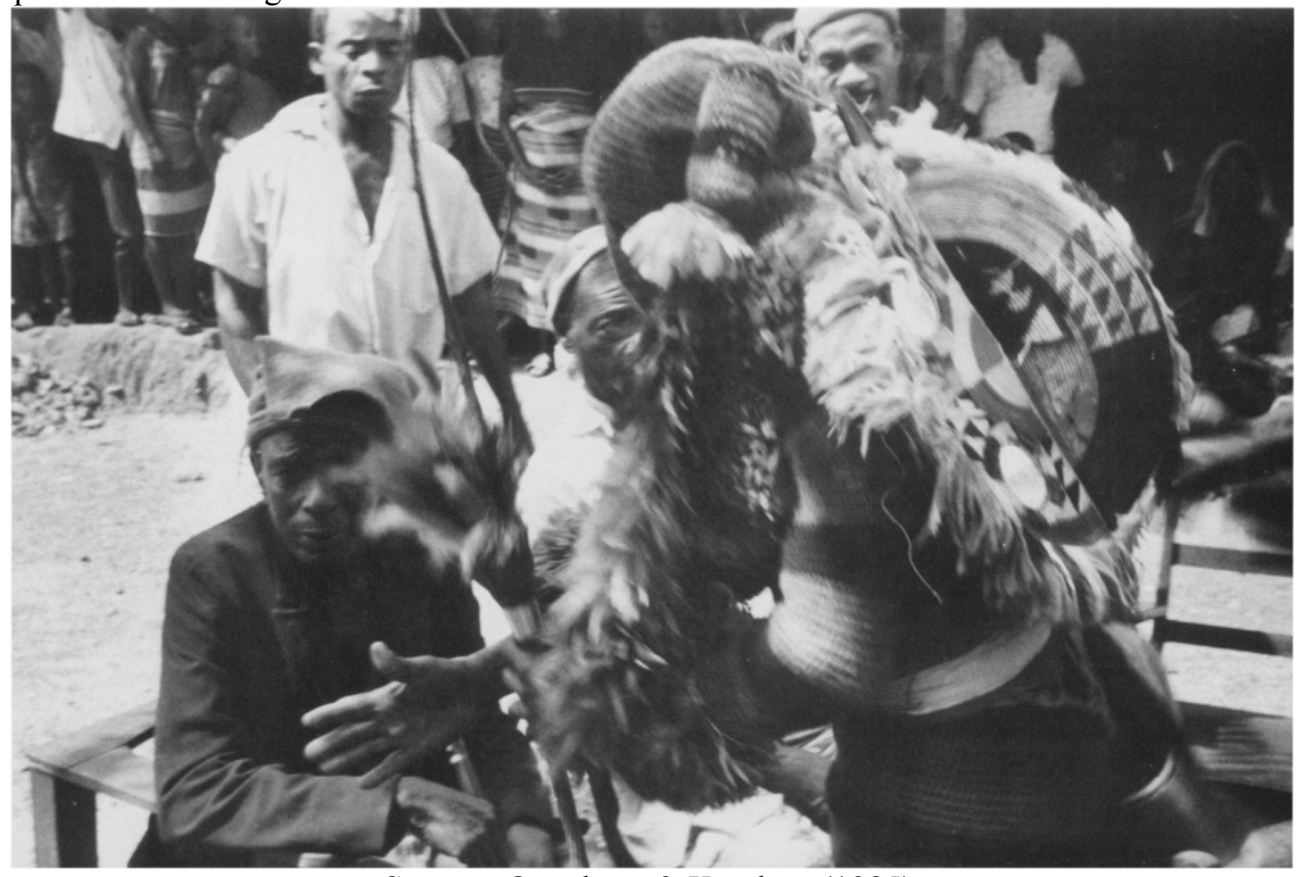

Source: Ottenberg \& Knudsen (1985). 